\title{
Deep drill hole in the Devonian South Mountain batholith, Nova Scotia: a potential for hidden mineral deposits within the batholith
}

\author{
A.K. Chatterjee and J. Dostal ${ }^{1}$ \\ Department of Geology, Saint Mary's University, Halifax, NS B3H 3C3, Canada \\ 1. Corresponding author: <jarda.dostal@smu.ca> \\ Date received:March 27,2002 Date accepted:August 11, 2002
}

\begin{abstract}
The drill hole near Digby in southwestern Nova Scotia is the deepest on-shore hole in the Canadian Appalachians, and penetrated to a depth of about $1.5 \mathrm{~km}$. The site of the drill was selected at the periphery of the Devonian South Mountain batholith, which contains important mineralization of tin and uranium. The drill hole intersected texturally uniform megacrystic biotite granodiorite, which does not display any pronounced primary vertical zonation. At depth, the drill core contains zones of alteration, fracturing, and brecciation. The alteration is mainly due to fluid flow along the fractures. Some fractures are mineralized and contain galena, sphalerite, pyrrhotite, chalcopyrite, pyrite, hematite, quartz, and carbonate minerals. Common occurrence of alteration zones in the hole suggests that such zones are widespread in the batholith and point to abundant hydrothermal activity deep within the massif. It is inferred that the potential for hidden economic mineral deposits within the batholith is much greater than is suggested by surface features. The association of mineralization as seen in the drill core with the most primitive rocks of the batholith further indicates that mineral deposits in granitoid rocks are not always hosted by the most evolved and fractionated rocks. Extensive fracturing demonstrates that the batholith is not a suitable candidate for the storage of radioactive waste material. High temperature measured in the drill hole $\left(\sim 68^{\circ} \mathrm{C}\right.$ at a depth of about $\left.1,450 \mathrm{~m}\right)$ suggests that the pluton has promise as a source of geothermal energy.
\end{abstract}

\section{RESUMÉ}

\begin{abstract}
Le puits de forage creusé près de Digby dans le Sud-Ouest de la Nouvelle-Écosse constitue le puits sur rivage le plus profond dans les Appalaches canadiennes; il s'enfonce à une profondeur d'environ 1,5 kilomètre. L'emplacement du trou de forage a été choisi à la périphérie du batholite dévonien du mont South, qui abrite une minéralisation importante d'étain et d'uranium. Le trou de forage a entrecoupé de la granodiorite à biotite phénocristalline à texture uniforme qui n'affiche aucun rubanement vertical primaire prononcé. En profondeur, la carotte de forage présente des zones d'altération, de fissuration et de bréchification. L'altération est principalement due à un écoulement de fluides le long des fissures. Certaines fissures sont minéralisées et renferment de la galène, de la sphalérite, de la pyrrhotine, de la chalcopyrite, de la pyrite, de l'hématite, du quartz et des carbonates. La présence fréquente de zones d'altération dans le trou permet de supposer que ces zones sont répandues dans le batholite et elle signale une activité hydrothermale abondante en profondeur à l'intérieur du massif. On en déduit que le potentiel de gîtes minéraux rentables cachés à l'intérieur du batholite est beaucoup plus vaste que ce que laissent supposer les caractéristiques à la surface. L'association de la minéralisation avec les roches les plus primitives du batholite dont témoigne la carotte révèle par ailleurs que les gîtes minéraux dans des roches granitiques ne sont pas toujours inclus dans les roches les plus évoluées et les plus fractionnées. Le degré de fissuration prononcé révèle que le batholite ne constitue pas un candidat convenable pour le stockage des déchets radioactifs. La température élevée relevée dans le trou de forage $\left(\sim 68^{\circ} \mathrm{C}\right.$ à une profondeur de $\left.1450 \mathrm{~m}\right)$ laisse supposer que le pluton représente une source prometteuse d'énergie géothermique.
\end{abstract}

\section{INTRODUCTION}

Three-dimensional geological information is vital to conceptually develop sophisticated metallogenic models for granitoid massifs (e.g., Cuney et al. 1985 1992; Arniaud et al. 1984). Conventional models based on near-surface data remain largely speculative. The Nova Scotia Department of Natural Resources initiated a deep-drilling program to study the compositional variability with depth of the granitoid rocks of the South Mountain batholith (SMB), the largest peraluminous granitoid body in the Appalachian orogen, which contains important mineralization of tin and uranium. Associated with this known mineralization are extensive alteration zones, the surface or near-surface expressions of which have been the targets of mineral exploration in recent years. The drill core provides an insight into deep-seated hydrothermal activity in the SMB and yield important data for petrological and metallogenic studies of peraluminous granites in Paleozoic foldbelts on a worldwide basis. The deep-drilling project also yielded information on the use of the granites as a depository of radioactive waste material and as a potential source of geothermal energy.

The purpose of this paper is to document the petrographic and geochemical characteristics of the core from the drill hole near Digby in southwestern Nova Scotia (Fig.1). The drill penetrated 


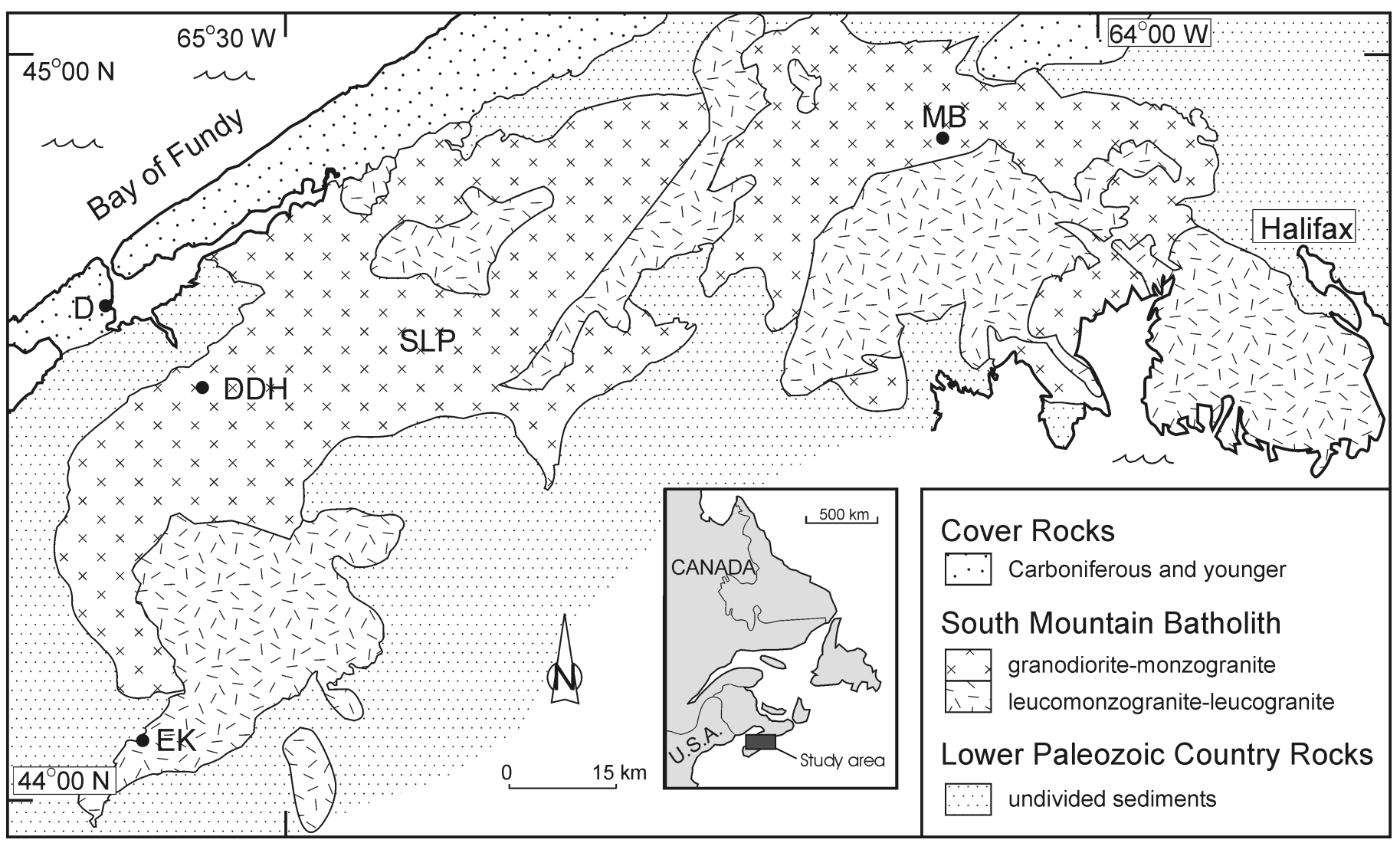

FIG. 1 Generalized geological map of southwestern Nova Scotia (modified from MacDonald et al. 1992 and Clarke et al. 1997) showing the South Mountain batholith and the locations of the drill hole (DDH), East Kemptville tin (EK) and Millet Brook uranium (MB) deposits, the Scrag Lake pluton (SLP) and the town of Digby (D). Insert map shows the location of the study area.

to a depth of about $1.5 \mathrm{~km}$ and is the deepest on-shore hole in the Canadian Appalachian orogen. The site of the drill hole was selected close to the periphery of the massif in order to intersect the least differentiated granitic rocks of the batholith. The results indicate hydrothermal activity deep within the SMB and potential mineralization, although there is no obvious expression of this at the surface.

\section{GEOLOGICAL SETTING}

The SMB, which intrudes Cambro-Ordovician turbiditic rocks of the Meguma Group and overlying Siluro-Devonian (Emsian) White Rock and Torbrook formations composed of volcanosedimentary sequences, crops out over an area of about 7,300 $\mathrm{km}^{2}$. The granitoid rocks of the SMB range from megacrystic biotite granodiorite (with up to $20 \%$ biotite) to equigranular leucogranite containing less than $2 \%$ biotite. All the granitoid rocks of the SMB are peraluminous, as expressed by the presence of corundum in the normative mineralogy and by the local occurrence of primary muscovite, cordierite, andalusite, garnet, and topaz. Mapping (Ham et al. 1990; Horne et al. 1991; MacDonald et al. 1992) has shown that the SMB is composed of several distinct plutons. Intrusive relationships among these bodies were established during field mapping and various geochronological studies based upon $\mathrm{Ar} / \mathrm{Ar}, \mathrm{Rb} / \mathrm{Sr}, \mathrm{U} / \mathrm{Pb}$ and $\mathrm{Pb} / \mathrm{Pb}$ indicate that the plutons intruded within a narrow time interval of less than 5 Ma at about 370 Ma ago (Reynolds et al. 1981, 1987; Kontak and Chatterjee 1992; Keppie and Dallmeyer 1994). The host sedimentary rocks of the Meguma Group and overlying formations were subjected to regional metamorphism ranging from lower greenschist to middle amphibolite facies during the Acadian orogeny, which has been dated at $400 \mathrm{Ma}$ (Reynolds et al. 1987; Hicks et al. 1999). The SMB was emplaced well after the peak of metamorphism and is unconformably overlain by sedimentary rocks of Namurian to Tournaisian age (Howie and Barss 1975). The batholith was emplaced at a depth equivalent to a pressure of about 4 $\mathrm{kb}$ and was uplifted and unroofed within about $10 \mathrm{Ma}$ (Clarke and Chatterjee 1988; Clarke et al. 1997). This short duration suggests that the unroofing was probably due to the final stages of collision between the Meguma and Avalon terranes.

The SMB hosts two important hydrothermal deposits: a large $\mathrm{U}(+\mathrm{Cu}-\mathrm{Ag}$ ) deposit at Millet Brook (Chatterjee and Strong 1984) in the northeastern part of the batholith and the East Kemptville tin deposit (Kontak 1994; Halter et al. 1996) located in southwestern Nova Scotia (Fig.1). The fracture-related vein-type U deposit of Millet Brook is hosted by biotite granodiorite (the least differentiated rock-type of SMB), whereas the tin deposit is enclosed in highly evolved topaz leucogranite (Dostal and Chatterjee 1995, 2000). Mineralization in both deposits is accompanied by alteration of the host granitoid rocks. The $\mathrm{U}$ mineralization is associated with intense hydrothermal alteration, whereas mas- 
sive quartz-topaz-cassiterite greisenization accompanies the tin mineralization. The age of the hydrothermal events and attending mineralization in both deposits is around $370 \mathrm{Ma}$ (Kontak and Chatterjee 1992; Keppie et al. 1993) and could be of great significance in terms of the metallogenic evolution of the SMB.

\section{DRILL HOLE}

The drill hole, located at Wallace Lake near Digby $\left(44^{\circ} 29^{\prime} 08.5^{\prime \prime}\right.$, $65^{\circ} 43^{\prime} 19.7^{\prime \prime}$, Fig.1), penetrated the northwestern portion of the Scrag Lake pluton. The pluton covers an area of $2,460 \mathrm{~km}^{2}$ and is composed of biotite granodiorite and biotite monzogranite in the proportion of 1:4. The biotite monzogranite is a medium to coarse grained rock (grain size 0.1 to $>0.5 \mathrm{~cm}$ ) with megacrystic to seriate texture composed of perthitic K-feldspar, zoned plagioclase, quartz, and biotite (10-17\%). Muscovite and ilmenite occur in accessory amounts. Compared to monzogranite, biotite granodiorite has higher proportion of plagioclase relative to Kfeldspar and higher contents of biotite (up to 20\%). In both rock types, biotite contains inclusions of apatite, zircon, monazite, and titanite.

Petrographic and airborne radiometric data show that the Scrag Lake pluton is zoned and the most primitive granitoid rocks occur in the northwestern part of the body (Horne et al. 1991), where the hole was drilled. The drill core was systematically documented; it contains four distinct zones with contrasting degrees of fracturing and associated alteration (Fig. 2). This division is also supported by borehole geophysical data: magnetic susceptibility, natural gamma-ray radiometry and induced-polarization (P. Kileen, personal communication, 1992).

\section{PETROGRAPHY}

The drill hole intersected texturally uniform megacrystic biotite granodiorite (according to the classification of Streckeisen 1976) with xenoliths of cleaved country rocks and others of unknown affinities. The four zones (Fig. 2) defined by petrographic and hand-specimen observations are (A) unaltered granodiorite which forms the drill core from 0 to $290 \mathrm{~m}$, (B) weakly altered granodiorite from $290 \mathrm{~m}$ to $550 \mathrm{~m},(\mathrm{C})$ altered and brecciated granodiorite from 550 to 1,100 $\mathrm{m}$ with mineralized fractures, and (D) alternating bands of unaltered and altered granodiorite from 1,100 to the bottom at a depth of about $1,450 \mathrm{~m}$ (Fig. 2). Fractures associated with the altered rocks are $0.5 \mathrm{~mm}$ to $2.5 \mathrm{~cm}$ wide. Some are mineralized and contain aggregates of galena, sphalerite, pyrrhotite, chalcopyrite, pyrite, hematite, quartz, and carbonate minerals, with minor amounts of U-phosphate and fluorite. Others are mostly filled by quartz, carbonate minerals, chlorite, kaolinite, and hematite. Adjacent to the fractures, the host rocks are strongly chloritized. Fracturerelated alteration extends for a distance of up to $2 \mathrm{~m}$ from the fractures although generally the distance is significantly less. There are typically 8 to 10 fractures per $1 \mathrm{~m}$ of drill core of the altered granodiorite and about $20 \%$ of this zone is intensely altered. In the weakly altered zone, about $5-10 \%$ of the rocks are altered.

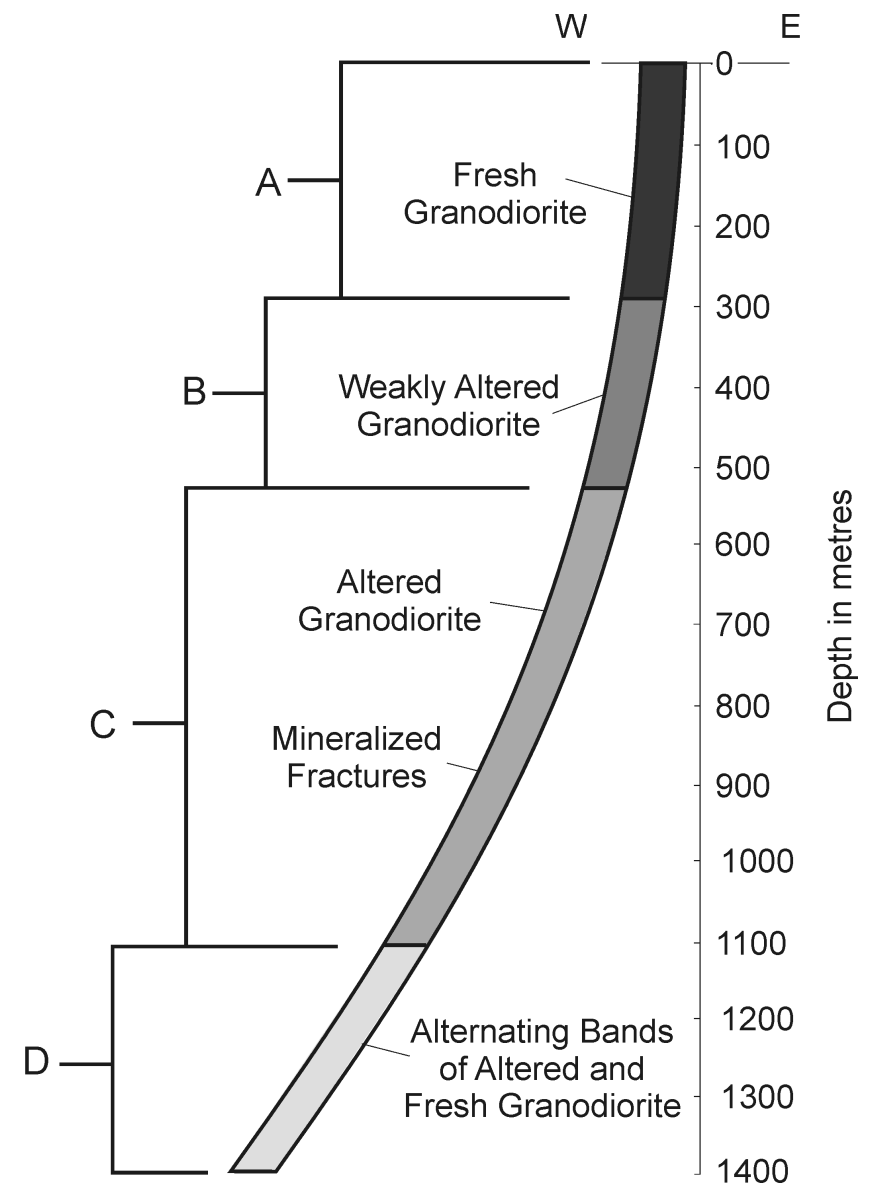

FIG. 2 The drill hole profile showing the distribution of fractures and alteration zones.

The xenoliths are present only in the upper part of the hole, in the unaltered granodiorite zone, and even in this zone, their abundance decreases with depth.

All fresh biotite granodiorite is composed primarily of quartz, plagioclase, K-feldspar, and biotite. Additionally, the rocks contain accessory garnet, apatite, zircon, monazite, and ilmenite. The composition of the plagioclase ranges from $\mathrm{An}_{37}$ in the core to $\mathrm{An}_{17}$ in the rim. Subordinate K-feldspar is typically perthitic. Biotite $(\sim 15-20$ vol. $\%)$ with $\mathrm{Mg}$ values $(\mathrm{Mg} / \mathrm{Mg}+\mathrm{Fe}+\mathrm{Mn})$ around 0.35 , normally forms large euhedral crystals (up to several $\mathrm{mm}$ in size) with prominent inclusions of apatite, monazite, and zircon.

Altered granodiorite typically contains hematite, quartz, carbonate minerals, chlorite, sericite, albite, and K-feldspar. The other associated hydrothermal minerals are epidote, titanite, chlorite, muscovite, tourmaline, and minor amounts of opaque minerals such as sphalerite, chalcopyrite, uraninite, and autunite. The most characteristic feature of the altered rocks is brittle deformation and pervasive degradation of plagioclase and biotite. Four distinct alteration types are recognized: albitization, potassic alteration, carbonatization, and silicification. These types typically occur together and form a continuum. The intensity of alteration increases towards the fracture zones.

Albitization is characterized by the presence of albite $\left(\mathrm{An}_{0-5}\right)$, which occurs as thin continuous rims on plagioclase, as euhedral 


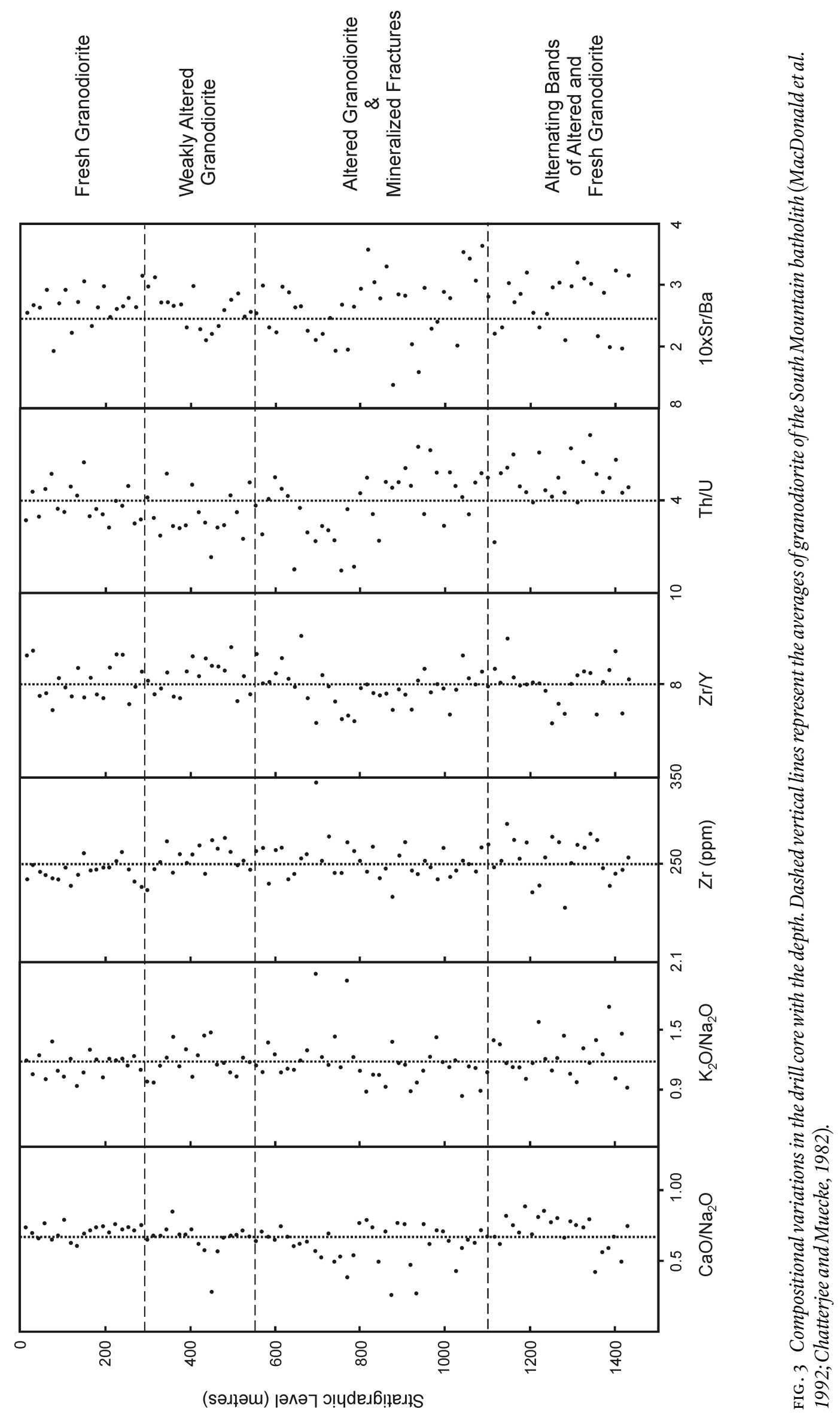


grains with quartz, and sparsely as small blebs with secondary biotite. In rare cases, albite forms veins up to $2 \mathrm{~cm}$ thick. Minor amounts of titanite are generally associated with albitized rocks.

Potassic alteration generates secondary K-feldspar (microcline), muscovite/sericite, and biotite. These minerals occur as discrete grains or are associated with primary minerals. The most distinct morphological feature is the replacement of plagioclase by secondary K-feldspar. Muscovite/sericite forms small flakes in the above association. Secondary biotite is devoid of inclusions and reaches up to $10 \%$ of volume. Epidote and carbonate minerals are also commonly produced during this alteration.

Carbonatization is defined by calcite, which occurs as veins and discrete grains (interstitial or associated with albite) or, together with chlorite and epidote, forms a matrix in strongly brecciated rocks. Carbonate minerals are normally accompanied by hematite.

Silicification is manifested by secondary quartz, which replaces plagioclase, K-feldspar, and biotite or occurs as thin stringers. In open spaces, secondary quartz forms euhedral crystals.

Rocks from depths of 290-550 m, the weakly altered zone, show only early stages of alteration and the primary magmatic mineral assemblage is dominant. Comparable weakly altered rocks also occur at a depth $>1,100 \mathrm{~m}$, although fresh and altered rocks are the predominant rock types of this zone.

\section{SAMPLING AND ANALYTICAL METHODS}

A total of 95 samples were taken from the drill core at approximately $15 \mathrm{~m}$ intervals (Fig. 3). Each sample represents a length of 15-20 cm of core. Major elements and the trace elements $\mathrm{Rb}$, $\mathrm{Ba}, \mathrm{Sr}, \mathrm{Zr}, \mathrm{Nb}, \mathrm{Y}, \mathrm{Ga}, \mathrm{Cr}, \mathrm{Ni}, \mathrm{V}, \mathrm{Cu}$ and $\mathrm{Zn}$ were analyzed by X-ray fluorescence methods at the Regional Geochemical Centre at Saint Mary's University. Precision is generally better than 5\% for the major oxides and between 5 to $10 \%$ for trace elements (Dostal et al. 1986). The concentrations of Th and U were determined by instrumental neutron activation and delayed neutron activation techniques, respectively, at Atomic Energy Commission of Canada, Ottawa. Rare-earth elements (REE) and Hf were determined in fourteen samples by inductively-coupled plasma-mass spectrometry (ICP-MS) using $\mathrm{Na}_{2} \mathrm{O}_{2}$ sinter fusion at Memorial University of Newfoundland. Precision is between 2 and $4 \%$ and Longerich et al. (1990) reported the details of the ICP-MS analytical procedure.

\section{GEOCHEMISTRY}

\section{Fresh granodiorite}

According to normative composition recast in terms of quartz (Q), alkali feldspar (A) and plagioclase (P) (LeMaitre 1989), most fresh rocks of the drill hole are of granodiorite composition and the rest straddle the boundary between the monzogranite and granodiorite fields (Fig. 4). Some altered samples plot into the monzogranite field towards the $\mathrm{A}$ apex (Fig. 4). Fresh rocks are peraluminous (i.e. molecular $\mathrm{Al}_{2} \mathrm{O}_{3} /\left(\mathrm{CaO}+\mathrm{K}_{2} \mathrm{O}+\mathrm{Na}_{2} \mathrm{O}\right)>1$ ) with

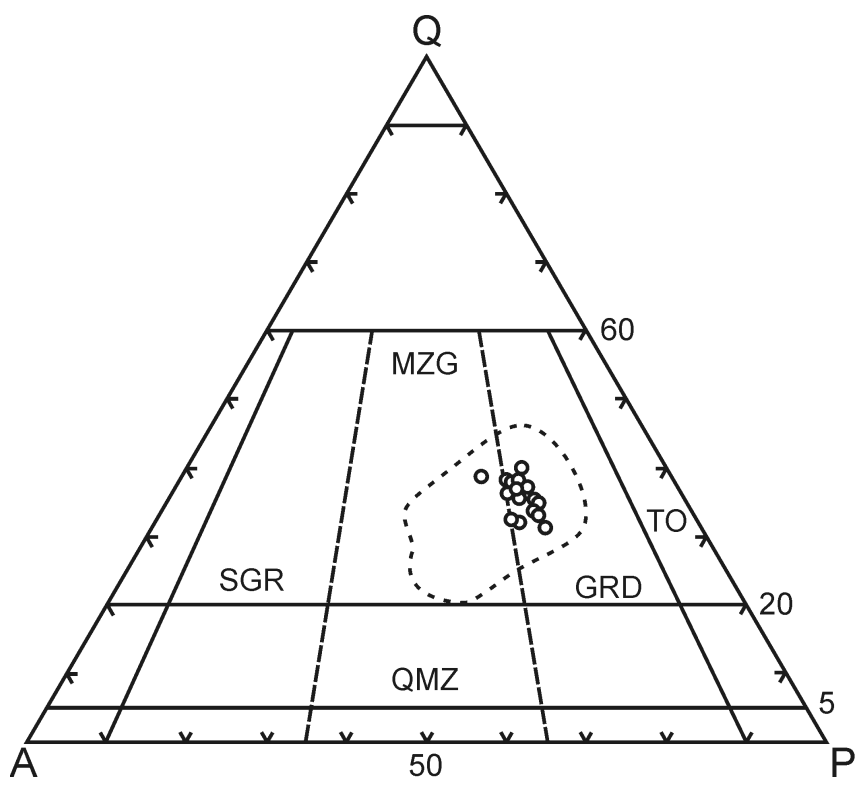

FIG. 4 Quartz-alkalifeldspar-plagioclase (QAP) plot for normative composition of the rocks of the drill hole. Fields (after Le Maitre 1989): SGR, syenogranite; MZG, monzogranite; QMZ, monzonite; $G R D$, granodiorite; TO, tonalite. Fresh rocks are shown as circles. The dashed line shows the field of the altered rocks.

$\mathrm{SiO}_{2}$ ranging from 65 to $68 \mathrm{wt} . \%$ and with $\mathrm{K} / \mathrm{Rb}$ ratios ranging from 190 to 250. Compared to the granodiorite samples of the Scrag Lake pluton collected on the surface (Ham et al. 1990), the rocks from the drill core have slightly lower contents of Th but higher $\mathrm{CaO}, \mathrm{MgO}, \mathrm{Sr}, \mathrm{Ba}$ and $\mathrm{Zr}$ (Table 1). Relative to the average of SMB biotite granodiorite given by MacDonald et al (1992), they are less evolved, and have lower contents of $\mathrm{SiO}_{2}$ (Fig. 5). The chondrite-normalized REE patterns of the drill core granodiorite samples are enriched in light REE with $(\mathrm{La} / \mathrm{Yb})_{\mathrm{n}} \sim 8$ to 11 and typically show a small but distinct negative Eu anomaly (Fig. 6). The patterns are similar to those of granodiorite from elsewhere in SMB (Muecke and Clarke 1981).

The fresh granodiorite samples define distinct variation trends for some major and trace elements where plotted against $\mathrm{SiO}_{2}$ (Fig.5) or other differentiation indices, suggesting that the rocks underwent fractional crystallization. Large variation of $\mathrm{Sr}$ accompanied by relatively constant $\mathrm{Rb} / \mathrm{Sr}$ (not shown) and $\mathrm{Mg} / \mathrm{Rb}$ ratios with increasing $\mathrm{SiO}_{2}$ (Fig. 5) suggest fractionation mainly of plagioclase and biotite.

Mass balance calculations using major element data (Bryan $e t$ al. 1969) show that the fresh sample with the lowest $\mathrm{SiO}_{2}$ content (sample 39; Table 2) taken to represent the most primitive and most likely parent magma can produce the sample of the zone A with the highest $\mathrm{SiO}_{2}$ (sample 27) by fractional crystallization of plagioclase and biotite in the proportion of 2.3:1. The calculations using the composition of the crystal core of both of these minerals imply a separation of $18.3 \%$ of this assemblage. The observed concentrations of $\mathrm{Rb}, \mathrm{Sr}$, and $\mathrm{Ba}$ are in good agreement with the calculated abundances obtained from an equilibrium fractional crystallization equation, implying that their distribu- 


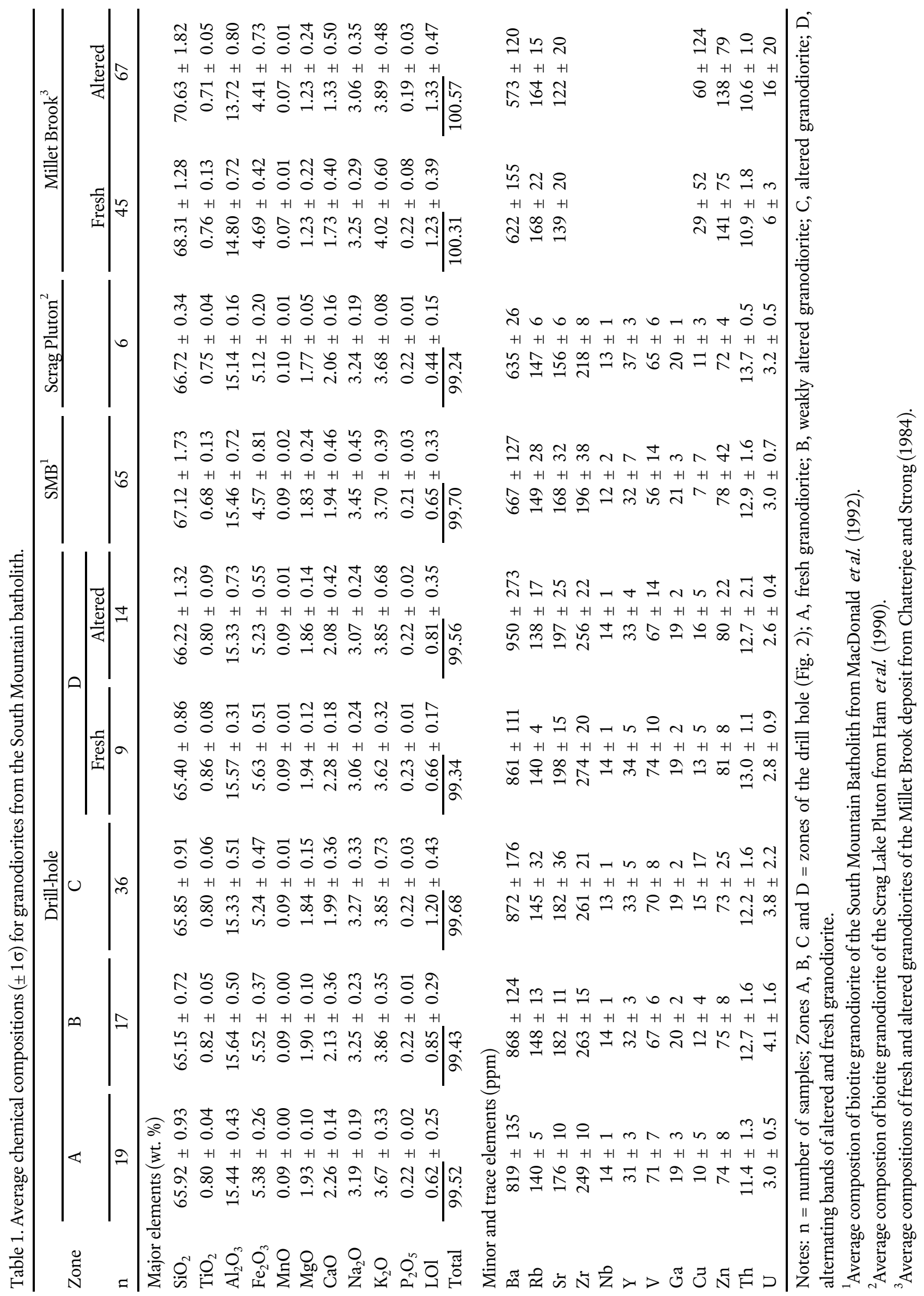



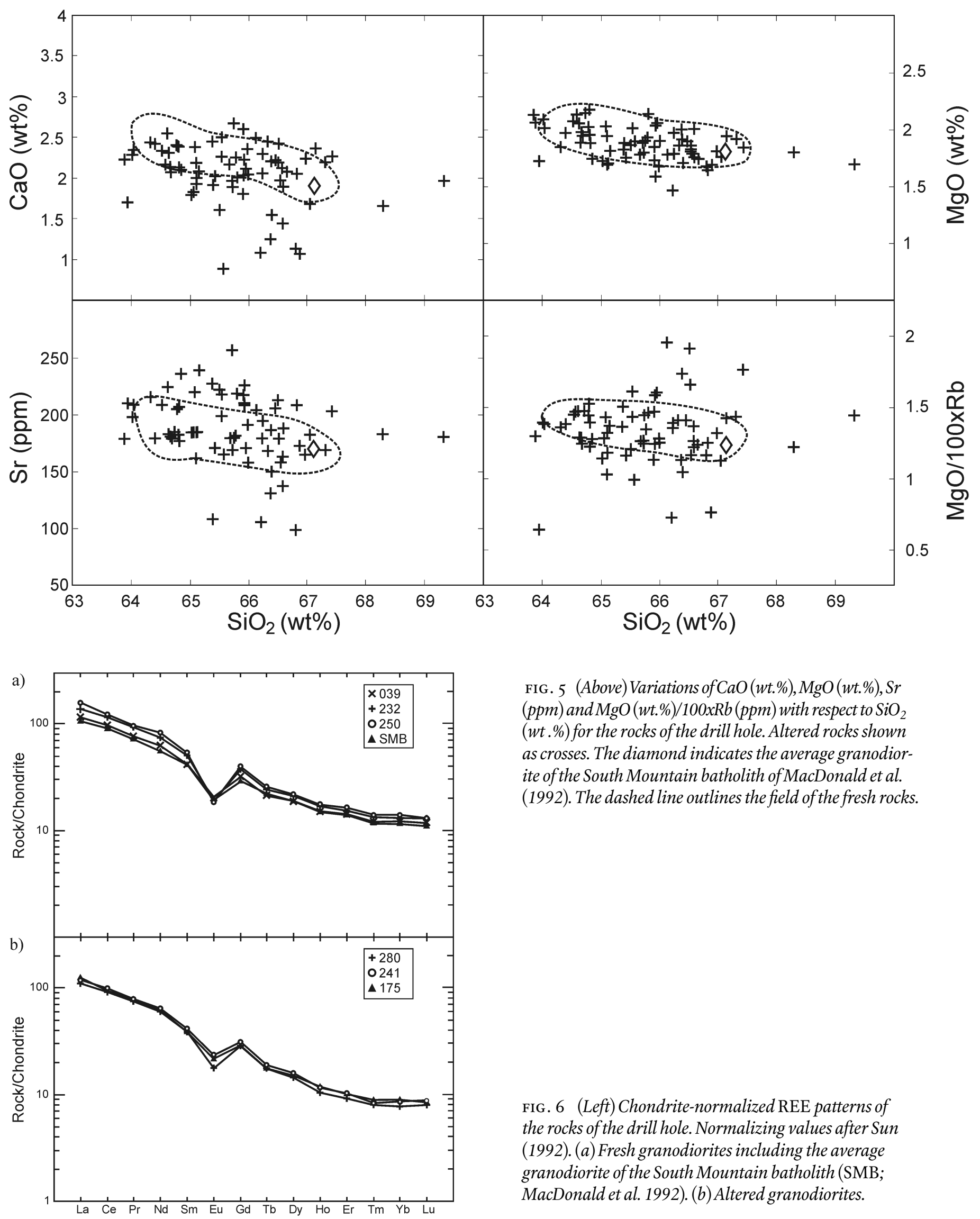

FIG. 5 (Above) Variations of $\mathrm{CaO}(w t . \%), \mathrm{MgO}(w t . \%), \mathrm{Sr}$ (ppm) and $\mathrm{MgO}(w t . \%) / 100 x \mathrm{Rb}(\mathrm{ppm})$ with respect to $\mathrm{SiO}_{2}$ (wt.\%) for the rocks of the drill hole. Altered rocks shown as crosses. The diamond indicates the average granodiorite of the South Mountain batholith of MacDonald et al. (1992). The dashed line outlines the field of the fresh rocks.

FIG. 6 (Left) Chondrite-normalized REE patterns of the rocks of the drill hole. Normalizing values after Sun (1992). (a) Fresh granodiorites including the average granodiorite of the South Mountain batholith (SMB; MacDonald et al. 1992). (b)Altered granodiorites. 
Table 2. Major and trace element compositions of representative rocks from the drill hole.

\begin{tabular}{|c|c|c|c|c|c|c|c|c|c|c|c|c|c|c|c|c|}
\hline \multirow{4}{*}{$\begin{array}{l}\text { Zone } \\
\text { Sample \# } \\
\text { depth }(m)\end{array}$} & \multicolumn{4}{|c|}{ Fresh } & \multicolumn{12}{|c|}{ Altered } \\
\hline & \multicolumn{2}{|c|}{ A } & \multicolumn{2}{|c|}{$\mathrm{D}$} & \multirow{2}{*}{$\begin{array}{c}\mathrm{B} \\
90\end{array}$} & \multicolumn{7}{|c|}{$\mathrm{C}$} & \multicolumn{4}{|c|}{ D } \\
\hline & 27 & 39 & 232 & 250 & & 139 & 129 & 145 & 157 & 175 & 187 & 154 & 241 & 277 & 274 & 280 \\
\hline & 135 & 195 & 1160 & 1250 & 450 & 695 & 645 & 725 & 785 & 875 & 935 & 770 & 1205 & 1385 & 1370 & 1400 \\
\hline \multicolumn{17}{|c|}{ Major elements (wt. \%) } \\
\hline $\mathrm{SiO}_{2}$ & 67.30 & 64.29 & 64.33 & 64.64 & 65.57 & 63.94 & 67.18 & 65.95 & 67.05 & 66.21 & 66.80 & 66.88 & 64.32 & 65.90 & 68.29 & 69.32 \\
\hline $\mathrm{TiO}_{2}$ & 0.76 & 0.78 & 0.92 & 0.98 & 0.87 & 0.96 & 0.73 & 0.89 & 0.80 & 0.69 & 0.76 & 0.79 & 0.71 & 0.67 & 0.77 & 0.71 \\
\hline $\mathrm{Al}_{2} \mathrm{O}_{3}$ & 14.93 & 16.52 & 15.83 & 15.67 & 14.47 & 15.85 & 15.00 & 14.95 & 14.75 & 15.95 & 15.13 & 15.10 & 16.96 & 16.00 & 14.53 & 14.01 \\
\hline $\mathrm{Fe}_{2} \mathrm{O}_{3}$ & 5.17 & 5.29 & 6.03 & 6.35 & 6.31 & 4.62 & 4.95 & 5.76 & 5.13 & 3.20 & 4.59 & 5.09 & 4.62 & 4.42 & 5.07 & 4.74 \\
\hline $\mathrm{MnO}$ & 0.09 & 0.09 & 0.10 & 0.09 & 0.10 & 0.08 & 0.08 & 0.10 & 0.08 & 0.06 & 0.07 & 0.10 & 0.08 & 0.08 & 0.09 & 0.09 \\
\hline $\mathrm{MgO}$ & 1.92 & 1.98 & 2.06 & 2.02 & 1.89 & 1.72 & 1.80 & 2.06 & 1.76 & 1.47 & 1.67 & 1.69 & 1.85 & 1.73 & 1.80 & 1.69 \\
\hline $\mathrm{CaO}$ & 2.19 & 2.60 & 2.42 & 2.44 & 0.88 & 1.70 & 1.96 & 2.11 & 1.68 & 1.08 & 1.13 & 1.07 & 1.44 & 1.80 & 1.66 & 1.97 \\
\hline $\mathrm{Na}_{2} \mathrm{O}$ & 3.62 & 3.50 & 3.23 & 3.14 & 3.10 & 2.98 & 3.22 & 3.05 & 3.09 & 4.06 & 4.13 & 2.75 & 3.56 & 3.03 & 2.94 & 2.94 \\
\hline $\mathrm{K}_{2} \mathrm{O}$ & 3.39 & 3.60 & 3.66 & 3.43 & 4.60 & 6.19 & 3.55 & 3.51 & 3.80 & 5.64 & 4.01 & 5.53 & 4.78 & 5.27 & 3.70 & 2.99 \\
\hline $\mathrm{P}_{2} \mathrm{O}_{5}$ & 0.20 & 0.29 & 0.24 & 0.24 & 0.23 & 0.25 & 0.20 & 0.23 & 0.21 & 0.20 & 0.21 & 0.21 & 0.21 & 0.20 & 0.21 & 0.19 \\
\hline LOI & 0.50 & 0.50 & 0.60 & 0.40 & 1.70 & 1.00 & 1.00 & 1.00 & 1.50 & 0.80 & 0.90 & 1.20 & 0.50 & 0.70 & 0.60 & 0.90 \\
\hline Total & $\overline{100.07}$ & 99.44 & 99.42 & 99.40 & 99.72 & $\overline{99.29}$ & 99.67 & 99.61 & 99.85 & 99.36 & 99.40 & $\overline{100.41}$ & $\overline{99.03}$ & 999.80 & 99.66 & 99.55 \\
\hline
\end{tabular}

Minor and trace elements (ppm)

\begin{tabular}{|c|c|c|c|c|c|c|c|c|c|c|c|c|c|c|c|c|}
\hline $\mathrm{Cr}$ & 50 & 50 & 70 & 72 & 54 & 41 & 54 & 55 & 55 & 45 & 58 & 37 & 52 & 56 & 60 & 64 \\
\hline $\mathrm{Ni}$ & 16 & 14 & 24 & 17 & 24 & 20 & 12 & 17 & 14 & 13 & 16 & 13 & 20 & 19 & 15 & 13 \\
\hline $\mathrm{V}$ & 71 & 66 & 80 & 86 & 61 & 83 & 67 & 73 & 79 & 68 & 69 & 71 & 60 & 55 & 63 & 38 \\
\hline $\mathrm{Cu}$ & 15 & 10 & 15 & 13 & 14 & 18 & 18 & 11 & 96 & 8 & 14 & 14 & 10 & 9 & 25 & 14 \\
\hline $\mathrm{Zn}$ & 71 & 82 & 86 & 96 & 86 & 107 & 75 & 81 & 43 & 37 & 34 & 176 & 73 & 70 & 74 & 148 \\
\hline $\mathrm{Rb}$ & 134 & 137 & 144 & 143 & 191 & 269 & 136 & 128 & 156 & 203 & 143 & 222 & 136 & 153 & 147 & 117 \\
\hline $\mathrm{Ba}$ & 752 & 807 & 870 & 781 & 950 & 1290 & 785 & 858 & 840 & 1180 & 895 & 1182 & 1042 & 1437 & 764 & 655 \\
\hline Sr & 169 & 202 & 196 & 194 & 165 & 210 & 170 & 171 & 183 & 106 & 99 & 173 & 216 & 217 & 183 & 181 \\
\hline $\mathrm{Ga}$ & 10 & 19 & 18 & 21 & 20 & 22 & 19 & 19 & 16 & 15 & 17 & 20 & 21 & 20 & 19 & 18 \\
\hline $\mathrm{Nb}$ & 13 & 14 & 15 & 16 & 14 & 15 & 13 & 15 & 12 & 11 & 13 & 13 & 13 & 15 & 13 & 13 \\
\hline $\mathrm{Hf}$ & & 7.01 & 7.42 & 7.44 & 6.08 & & 6.86 & 7.73 & 7.57 & 5.21 & 5.88 & 6.42 & 5.69 & 5.84 & & 5.63 \\
\hline $\mathrm{Zr}$ & 245 & 253 & 283 & 286 & 283 & 345 & 246 & 286 & 271 & 222 & 246 & 281 & 227 & 234 & 252 & 246 \\
\hline Y & 28 & 34 & 34 & 45 & 32 & 54 & 33 & 36 & 42 & 32 & 30 & 42 & 28 & 27 & 31 & 26 \\
\hline Th & 11.0 & 12.0 & 15.0 & 13.0 & 15.0 & 15.0 & 11.0 & 15.0 & 13.0 & 10.0 & 12.0 & 12.0 & 11.0 & 10.0 & 14.0 & 15.0 \\
\hline $\mathrm{U}$ & 2.6 & 3.5 & 2.5 & 3.1 & 9.5 & 6.6 & 2.8 & 5.5 & 11.0 & 2.2 & 1.9 & 3.3 & 2.8 & 2.0 & 3.2 & 2.6 \\
\hline $\mathrm{La}$ & & 38.08 & 45.46 & 52.14 & 40.03 & & 36.18 & 41.81 & 50.53 & 41.42 & 30.59 & 39.73 & 39.46 & 35.21 & & 36.26 \\
\hline $\mathrm{Ce}$ & & 83.96 & 100.00 & 106.71 & 89.61 & & 79.36 & 92.25 & 109.67 & 81.62 & 65.80 & 89.48 & 86.18 & 76.91 & & 80.98 \\
\hline $\operatorname{Pr}$ & & 9.97 & 12.02 & 12.52 & 10.48 & & 9.64 & 11.16 & 13.08 & 10.12 & 8.26 & 10.44 & 10.23 & 9.06 & & 9.65 \\
\hline $\mathrm{Nd}$ & & 39.75 & 47.10 & 52.51 & 41.92 & & 37.42 & 44.07 & 50.91 & 38.74 & 32.72 & 41.53 & 40.52 & 36.46 & & 37.98 \\
\hline $\mathrm{Sm}$ & & 8.46 & 10.31 & 10.84 & 8.98 & & 7.95 & 9.52 & 11.08 & 7.91 & 7.21 & 8.30 & 8.43 & 7.63 & & 7.83 \\
\hline $\mathrm{Eu}$ & & 1.59 & 1.52 & 1.41 & 1.38 & & 1.49 & 1.53 & 1.72 & 1.65 & 1.44 & 1.86 & 1.82 & 1.67 & & 1.37 \\
\hline Gd & & 8.92 & 10.39 & 11.08 & 9.30 & & 8.47 & 9.66 & 11.26 & 7.90 & 7.24 & 8.17 & 8.60 & 7.74 & & 7.99 \\
\hline $\mathrm{Tb}$ & & 1.07 & 1.20 & 1.28 & 1.08 & & 1.05 & 1.15 & 1.31 & 0.87 & 0.85 & 0.98 & 0.94 & 0.84 & & 0.89 \\
\hline Dy & & 6.49 & 7.25 & 7.39 & 6.67 & & 6.39 & 6.80 & 7.62 & 5.21 & 5.04 & 5.22 & 5.49 & 4.90 & & 5.00 \\
\hline Ho & & 1.16 & 1.30 & 1.35 & 1.16 & & 1.18 & 1.19 & 1.37 & 0.91 & 0.89 & 0.93 & 0.90 & 0.77 & & 0.81 \\
\hline Er & & 3.22 & 3.49 & 3.66 & 3.02 & & 3.20 & 3.14 & 3.52 & 2.29 & 2.22 & 2.34 & 2.33 & 2.00 & & 2.08 \\
\hline $\mathrm{Tm}$ & & 0.43 & 0.47 & 0.49 & 0.41 & & 0.45 & 0.43 & 0.49 & 0.31 & 0.29 & 0.31 & 0.29 & 0.25 & & 0.28 \\
\hline $\mathrm{Yb}$ & & 2.68 & 2.92 & 3.06 & 2.64 & & 2.65 & 2.57 & 2.86 & 1.98 & 1.77 & 1.83 & 1.91 & 1.64 & & 1.71 \\
\hline $\mathrm{Lu}$ & & 0.40 & 0.44 & 0.44 & 0.37 & & 0.40 & 0.41 & 0.45 & 0.29 & 0.28 & 0.26 & 0.30 & 0.25 & & 0.27 \\
\hline
\end{tabular}

Zones A, B, C and D are lithologic zones of the drill hole (Fig. 2). A, fresh granodiorite; B, weakly altered granodiorite; C, altered granodiorite; D, alternating bands of altered and fresh granodiorite.

\section{Altered Granodiorite}

tion is controlled predominantly by fractional crystallization. This calculation confirms that a closed-system fractional crystallization model can explain most of the evolution of the granodiorite units. MacDonald and Clarke (1991) suggested that the fractional crystallization in SMB was achieved by gravitational and flowage separation of crystals and liquids.
The averages of the weakly and strongly altered zones as well as the altered rocks from the lowermost zone are similar to those of the fresh rocks from the drill core (Table 1). The alteration of the granodiorite leads to a larger variation of concentrations of most elements as also shown by larger standard deviations in the altered rocks compared to the fresh rocks (Table 1). Only a few 
altered samples show compositional characteristics distinctly different from the fresh rocks. Moderate to weak brittle deformation, accompanied by potassic alteration and/or albitization, caused a decrease of $\mathrm{Ca}$, and an increase of $\mathrm{K}$ and $\mathrm{Ba}$ (Table 2). Silicification, characterized by numerous stringers of quartz, mainly resulted in a dilution effect without noticeable chemical changes of trace elements (samples 274 and 280, Table 2). Both these processes did not noticeably modify the REE and high-field-strength elements (HFSE). Intense shearing, leading to extreme granulation (sample 139 , Table 2), produced a pronounced increase of $\mathrm{K}, \mathrm{Rb}, \mathrm{Ba}, \mathrm{Zr}$, and $Y$ accompanied by the fractionation of ratios involving even HFSE such as $\mathrm{Zr} / \mathrm{Y}$ and $\mathrm{Zr} / \mathrm{Nb}$.

\section{DISCUSSION AND CONCLUSION}

The rocks in the drill core do not show a pronounced primary vertical zonation (Fig. 3) although the abundances of some elements and the element ratios, particularly $\mathrm{Th} / \mathrm{U}$, in the alteration zones show a larger scatter than in the fresh rocks. The fresh rocks from the lower part of the drill core have chemical compositions close to those from the top part, indicating that the granodioritic magma was fairly homogeneous. This limited primary compositional variation can be mostly explained by closed-system fractional crystallization of plagioclase and biotite.

The strongly sheared samples (such as sample 139, Table 2) have geochemical characteristics comparable to the mineralized zones containing chalcopyrite, pyrite, sphalerite, and autunite from the Millet Brook deposit (Chatterjee and Strong 1984), although the alteration intensity and elemental enrichment are much less pronounced in the drill core samples (Table 1). The similarity of chemical signatures generated by the mineralization and intense alteration in the Millet Brook deposit and the strongly altered samples from the drill core suggests that the alteration may be related to the same hydrothermal process. The altered zone encountered in the drill hole may represent channelways for the migration of mineralizing hydrothermal fluids or represent the deeper-seated roots of a shallow deposit/mineralization.

The association of alteration with fractures in both the drill core and in other areas throughout the SMB implies that the alteration is due to fluid flow along the fractures. In the Millet Brook deposit, Chatterjee and Strong (1985) inferred from oxygen isotopic data that the alteration is caused by fluids formed during fractionation of granitic magma. This interpretation is supported by dating of the Millet Brook deposit ( 370 Ma; Kontak and Chatterjee 1992; Keppie et al. 1993), which indicates that magmatism, alteration, and mineralization are approximately coeval. It suggests that the alteration of the rocks in the drill core was mainly produced by fluids derived during the cooling of the batholith. Minerals of the wall-rocks and fracture fillings imply that the fluids were oxidizing and at low temperature.

Most of the chemical variation in the altered rocks of the drill core can be correlated with the observed mineralogical changes. Albitization and sericitization of plagioclase led to the mobilization of $\mathrm{Ca}$ whereas elevated concentrations of $\mathrm{K}$ and $\mathrm{Ba}$ seem to be related to the newly formed hydrothermal K-feldspar.
Degradation of biotite probably resulted in mobilization of Ti, $\mathrm{Y}$, and $\mathrm{Zr}$, whereas the higher concentrations of $\mathrm{U}$ appear to be due to the presence of minute amounts of U-phosphate. The average compositions of the three zones as well as the compositions of most samples are similar, implying only limited mobility of elements.

If similar alteration zones are widespread elsewhere in the batholith, this study indicates that the potential for hidden economic mineral deposits is much greater than suggested by surface features. Therefore, our results may have significant implications for exploration in the SMB and other peraluminous granitic bodies. The association of mineralization, as seen in the drill core and also Millet Brook deposit, with the most primitive rocks of the batholith further documents that economic mineral deposits in granitoid rocks are not always hosted by the most evolved and fractionated rocks, although these later phases may play an important role in their genesis as documented for the Millet Brook uranium mineralization. Chatterjee and Strong (1984) concluded that the uranium mineralization is hosted by the least differentiated biotite granodiorite but is genetically associated to monzogranite and leucogranite.

Our research also suggests that due to intensity and extent of fracturing within the SMB, the batholith is not a suitable candidate for the storage of the radioactive waste material. However, high temperatures measured in the drill hole $\left(\sim 68^{\circ} \mathrm{C}\right.$ at a depth of about $1,450 \mathrm{~m}$ ) implies that the granite has promise as a source of geothermal energy.

\section{ACKNOWLEDGEMENTS}

This work was funded by the Nova Scotia Department of Natural Resources and NSERC. Critical comments by reviewers Dan Kontak and Linda Ham and journal editor Sandra Barr significantly improved the manuscript.

\section{REFERENCES}

Arniaud, D., Dupuy, C., \& Dostal, J. 1984. Geochemistry of Auriat granite (Massif Central, France). Chemical Geology, 45, pp. 263-277.

Bryan, W.B., Finger, L.W., \& Chayes, F. 1969. Estimating proportions in petrographic mixing equations by least-squares approximation. Science, 163, pp. 926-927.

Chatterjee, A.K., \& Muecke, G.K. 1982. Geochemistry and the distribution of uranium and thorium in the granitic rocks of the South Mountain Batholith, Nova Scotia: some genetic and exploration implications. In Uranium in Granites. Edited by Y.T. Maurice, Geological Survey of Canada, Paper 81-23, pp. 11-17.

Chatterjee, A.K., \& Strong, D.F. 1984. Discriminant and factor analysis of geochemical data from granitoid rocks hosting the Millet Brook uranium mineralization, South Mountain batholith, Nova Scotia. Uranium, 1, pp.289-305.

Chatterjee, A.K., \& Strong, D.F. 1985. Geochemical char- 
acteristics of the polymetallic tin domain, southwestern Nova Scotia, Canada. In Granite-related Mineral Deposits. Edited by R.P. Taylor and D.F. Strong, Canadian Institute of Mining and Metallurgy, pp. 41-52.

Clarke, D.B., \& Chatterjee, A.K. 1988. Physical and chemical processes in the South Mountain Batholith. In Recent advances in the geology of granite-related mineral deposits. Edited by R.P. Taylor and D.F. Strong. Canadian Institute of Mining and Metallurgy, Special Volume 39, pp. 223-233.

Clarke, D.B., MacDonald, M.A., \& Tate, M.C. 1997. Late Devonian mafic-felsic magmatism in the Meguma Zone, Nova Scotia. In The Nature of Magmatism in the Appalachian Orogen. Edited by A.K. Sinha,. J.B. Whalen, and J.P. Hogan, Geological Society of America Memoir 191, pp. 107-127.

Cuney, M., Autran, A., \& Burnol, L. 1985. Premiers résultats apportes par le sondage GPF de $900 \mathrm{~m}$ réalise sur le granite sodo-lithique et fluore a mineralisation disséminée de Beauvoir. Chronique de Recherche Minière, 481, pp. 59-63.

Cuney, M., Marignac, C., \& Weisbrod, A. 1992. The Beauvoir topaz-lepidolite albite granite (Massif Central, France): the disseminated magmatic Sn-Li-Ta-Nb-Be mineralization. Economic Geology, 87, pp. 1766-1794.

Dostal, J., Baragar, W.R.A., \& Dupuy, C. 1986. Petrogenesis of the Natkusiak continental basalts, Victoria Island, N.W.T. Canadian Journal of Earth Sciences, 23, pp. 622-632.

Dostal, J., \& Chatterjee, A.K. 1995. Origin of topaz-bearing and related peraluminous granites of Late Devonian Davis Lake pluton, Nova Scotia, Canada: crystal versus fluid fractionation. Chemical Geology, 123, pp. 67-88.

Dostal, J., \& Chatterjee, A.K. 2000. Contrasting behaviour of $\mathrm{Nb} / \mathrm{Ta}$ and $\mathrm{Zr} / \mathrm{Hf}$ ratios in a peraluminous granitic pluton (Nova Scotia, Canada). Chemical Geology, 163, pp. 207-218.

Halter, W.E., Williams-Jones, A.E., \& Kontak, D.J. 1996. The role of greisenization in cassiterite precipitation at the East Kemptville tin deposits, Nova Scotia. Economic Geology, 91, pp. 368-385.

Ham, L.J., Corey, M.C., Horne, R.J., \& MacDonald, M.A. 1990. Lithogeochemistry of the western portion of the South Mountain batholith, Nova Scotia, NTS map sheets 21A/3, $21 \mathrm{~A} / 4,21 \mathrm{~A} / 5,21 \mathrm{~A} / 6,21 \mathrm{~A} / 11,21 \mathrm{~A} / 12$ and $21 \mathrm{~A} / 14$. Nova Scotia Department of Mines and Energy, Open File Report 90-007.

Hicks, R.J., Jamieson, R.A., \& Reynolds, P.H. 1999. Detrital and metamorphic ${ }^{40} \mathrm{Ar} /{ }^{39} \mathrm{Ar}$ ages from muscovite and wholerock samples, Meguma Supergroup, southern Nova Scotia. Canadian Journal of Earth Sciences, 36, pp. 23-32.

Horne, R.J., Corey, M.C., Ham, L.J., \& MacDonald, M.A. 1991. Variation in the mafic mineral content of the Scrag Lake pluton, South Mountain Batholith: evidence for a zoned pluton. In Mines and Minerals Branch Report of Activities 1990. Edited by D.R. MacDonald, Nova Scotia Department of Mines and Energy, Report 91-1, pp. 49-60.

Howie, R.D., \& BARss, M.S. 1975. Upper Paleozoic rocks of the Atlantic Provinces, Gulf of St. Lawrence, and adjacent continental shelf. In Offshore Geology of Eastern Canada. Geological Survey of Canada, Paper 74-30, 258 pp.
Keppie, J.D., \& Dallmeyer, R.D. 1994. Late Paleozoic collision, delamination, short-lived magmatism and rapid denudation in the Meguma Terrane (Nova Scotia, Canada): constraints from ${ }^{40} \mathrm{Ar} /{ }^{39} \mathrm{Ar}$ isotopic data. Canadian Journal of Earth Sciences, 32, pp. 644-659.

Keppie, J.D., Aftalion, M., Dallmeyer, R.D., \& Krogh, T.E. 1993. Dating mineralization using several isotopic methods: an example from the South Mountain Batholith. Chemical Geology, 103, pp. 251-270.

KonTAK, D.J. 1994. Geological and geochemical studies of alteration processes in a fluorine-rich environment: The East Kemptville Sn-(Zn-Cu-Ag) deposit, Yarmouth County, Nova Scotia, Canada. In Alteration and Alteration Processes associated with Ore-forming Systems. Edited by D.R. Lentz, Geological Association of Canada, Short Course Notes 11, pp. 261-314.

Kontak, D.J., \& ChatterJee, A.K. 1992. The East Kemptville tin deposit, Yarmouth County, Nova Scotia: a Pb-isotope study of the leucogranite and mineralized greisens-evidence for a 366 Ma metallogenic event. Canadian Journal of Earth Sciences, 29, pp. 1180-1196.

Le Maitre, R.W. 1989. A classification of igneous rocks and glossary of terms. Blackwell Scientific, Oxford, U.K., 193 pp.

Longerich, H.P., JenNer, G.A., Fryer, B.J., \& Jackson, S.E. 1990. Inductively coupled plasma-mass spectrometric analysis of geological samples: A critical evaluation based on case studies. Chemical Geology, 83, pp. 105-118.

MacDonald, M.A., \& ClaRKe, D.B. 1991. Use of nonparametric ranking statistics to characterize magmatic and post-magmatic processes in the eastern South Mountain Batholith, Nova Scotia, Canada. Chemical Geology, 92, pp. 1-20.

MacDonald, M.A., Horne, R.J., Corey, M.C., \& Ham, L.J. 1992. An overview of recent bedrock mapping and follow-up petrological studies of the South Mountain Batholith, southwestern Nova Scotia, Canada. Atlantic Geology, 28, pp. 7-28.

Muecke, G.K., \& Clarke, D.B. 1981. Geochemical evolution of the South Mountain Batholith, Nova Scotia: rare-earth element evidence. Canadian Mineralogist, 19, pp. 133-145.

Reynolds, P.H., Zentilli, M., \& Muecke, G.K. 1981. K-Ar and ${ }^{40} \mathrm{Ar} /{ }^{39} \mathrm{Ar}$ geochronology of granitoid rocks from southern Nova Scotia: its bearing on the geological evolution of the Meguma Zone of the Appalachians. Canadian Journal of Earth Sciences, 18, pp. 386-394.

Reynolds, P.H., Elias, P., Muecke, G.K., \& Grist, A.M. 1987. Thermal history of the southwestern Meguma Zone, Nova Scotia, from an ${ }^{40} \mathrm{Ar} /{ }^{39} \mathrm{Ar}$ and fission track dating study of intrusive rocks. Canadian Journal of Earth Sciences, 24, pp.1952-1965.

STRECKEISEN, A. 1976. To each plutonic rock its proper name. Earth Science Review, 12, pp.1-33.

Sun, S.S. 1982. Chemical composition and origin of the Earth's primitive mantle. Geochimica et Cosmochimica Acta, 46, pp. 179-192.

Editorial responsibility: Sandra M. Barr 